\title{
Effects of Multimedia Instructional Strategy on Senior School Students' Performance and Retention in Mathematics
}

\author{
Ayodeji John Enikanolaye \\ Department of Science Education, Faculty of Education, University of Ilorin, Ilorin, Nigeria, \\ enikanolayeayodeji@gmail.com.
}

Student poor performance in mathematics has been a serious concern to mathematics educators and all educational stakeholders in Nigeria. The instructional strategies used by teachers in teaching mathematics have been identified by researchers as one of the problems behind this poor performance in mathematics. If this poor performance of students in mathematics continues it could deny the realization of educational goals for scientific and technological development of the nation. This research therefore, was carried out to examine the effects of multimedia instructional strategy on senior school students' performance and retention in mathematics in Ilorin, Kwara State, Nigeria. The study was a quasi-experimental type of the pre-test, post-test, non- randomized, control group design. The design is a $2 \times 2 \times 1$ factorial design. A sample of 81 senior secondary school II students from two secondary schools in Ilorin south local government area of Kwara State was involved. The research instruments were; developed multimedia instructional package. The experimental group was taught using multimedia instructional strategy, while the control group was exposed to the conventional teaching. Data collected for analysis were subjected to ANCOVA and t-Test statistics. From the study, findings showed that: (1) there was a significant difference between the experimental groups taught mathematics using multimedia and the control group taught mathematics using conventional method (2) both female and male students were capable of competing in classroom activities when taught with a better instructional strategy (3) multimedia instructional strategy improve and stimulate students' retention level thus, multimedia instructional package helps to concretize the learning of mathematics and makes learning more effective. Based on the findings of this study, it was recommended that multimedia instructional strategy may be integrated into mathematics curriculum and also used to arouse students' interest in mathematics.

Keywords: effects, multimedia, instructional strategy, mathematics, information and communication technology, gender, retention

\section{INTRODUCTION}

Mathematics is a science that have to do with numbers, space and quantity of which geometry, trigonometry, algebra and arithmetic are branches. Mathematics is one of the most central components of human thought, it is considered to be one of the oldest fields of study in the history of mankind (Mohamed, 2010). The researcher stated further that it has been believed for centuries that mathematics sharpens the human mind, develops their logical thinking; enhances reasoning ability and spartial power. The teaching and learning of mathematics should be taking seriously, since mathematics is about solving problems (Akinoso, 2015). The researcher further stated that mathematics is useful in the following area: keeping of records such as addition, subtraction, division and multiplication of numbers, money, length, mass and time; vocations such as carpentry, tailoring and plumbing which need the basic knowledge of geometry involving measurement, angle, symmetry

Citation: Enikanolaye, A. J. (2021). Effects of multimedia instructional strategy on senior school students' performance and retention in mathematics. Anatolian Journal of Education, 6(2), 193-206. https://doi.org/10.29333/aje.2021.6214a 
and plane shapes; mathematics is also useful in other subjects such as science, geography, accounting and economics. For example, the knowledge of mathematics is needed to calculate population density and gradient (Akinoso, 2015). This useful nature of mathematics carries with it the assumption that the knowledge of mathematics is substantive for all members of the society (Enikanolaye, Salman, Akanmu \& Salami, 2017).

Despite the important of mathematics in our daily activities and our educational system with effort made by researchers and mathematics educators to enhance performance in mathematics, it is very worrisome that students' performance in mathematics is still low (chief Examiner Report, 2010-2016). Several factors have been identified for students' poor performance in mathematics such as usage and availability of teaching and learning facilities, teachers' method of mathematics teaching (Mbugua, 2012). The teaching and learning of mathematics topics has been frustrated by the nature of the topics, the clumsy method and instructional strategy used by the teacher therefore resulting to students' poor performance in both internal and external examinations (Iji, Emiakwu \& Utubaku, 2015). Mathematics has been referred to as the language used to narate issues arising in most branches of sciences and technology because of its relationship with other school subjects (Agnes, Anthony, \& Julie, 2009). The performance of students in the outcome of mathematics exercise depends on how much interest the students have in the subject as performance processes have been viewed by; the characteristics of students and their environment, utilization of teaching-learning models, and instructional materials among others (Agnes, Anthony, \& Julie, 2009). Olive and makar (2010) posited that if mathematics is considered as a knowlwdge of fixed body to be learned, so the position of technology in this process would be mostly that of an efficacy tool i.e assisting student in doing mathematics in an efficient way.

However, if teachnological tools is consider as an access which provide new understandings of purpose, process and relations, then technology position relates to a conceptual construction kit. Therefore, when technology is integral part of the environment, it is more than just substitute for work done mathematical with paper and pencil (Merrilyn, 2010). Olive and Makar (2010), asserted that mathematical knowledge and mathematical practices are in extricably linked, and that this connection can be strengthened by the use of technologies. Idris (2007) in trying to provide alasting solution to the ugly situation of poor performance in public examination identified poor teaching and learning techniques as one of the contributing factors. Therefore, the involvement of students in the teaching and learning process which is a departure from conventional method of teaching is another means of ensuring a productive learning. The use of concrete representation of the instructional strategy can assist to learn a concept in mathematics and allow the use of real-life material that can be seen (Akinoso, 2015).

This $21^{\text {st }}$ century is being dominated by the use of information and communication technology (ICT). ICT has made a sudden change from the conventional paradigm of teaching and learning to more interesting way of teaching and learning. The use of ICT now make people connect to carried out activities online desired. Tinio (2003) asserted that integration of information communication and technology into education is in diverse and difficult processes that involves not only technology but teachers' competence, instructional readiness, pedagogy and curriculum among others. Researchers such as Mcintosh, Oliveras, Sullivan and Whitson (1996) stated that with the use of ICT, the role of teachers would change from being "transferers" of a predefined body of knowledge to being "managers" and "mentors" of learning. Tinio (2003) stated that ICT components such as mobile phones, computers and internet among others are potentially important enabling tools to bring about global educational change and reforms. The researcher further noted that when different ICT are used appropriately, they facilitate teaching and learning in education by raising the quality of education. ICT comprises of the medium for information recording like television and radio and communication through sound and voice or image using loudspeaker, telephone, camera and microphone (Osu, Udosen \& Akpan, 2010). 
Albirini (2006) posited that ICT is to be programmed towards the set educational goals. kyriakidou, chrisostomou and bank (2010) asserted that it is a compulsory issue for experience mathematics teachers to be confident in using ICT effectively in teaching. ICT is a broad term that encompases retrieval, storage, gathering and organisation of information that can be in numerical, vocal, textual and pictorial form or combination of all the forms known as multimedia. Muultimedia involve the computer-controlled integration of text, drawing, graphics, still and moving images (video), audio and animation (Kumar, 2013). Multimedia is used in educational sector, mass communication and advertising. Multimedia such as animation, graphics, video and text which create in interractive learning environment assist teacher and learner in deep reflective thinking. According to lindstrom (1994) students remember $40 \%$ of what they see and hear, $20 \%$ of what they see, but about $75 \%$ what they see, hear and do. Multimedia learning occurs when students use information presented in two or more formats-such as a virtually presented and animation presented narration-to construct knowledge (chapman, 2013). The researcher further stated that the use of multimedia in teaching and learning has the potential to improve instruction by creating a technology based and student centered learning environment.

Multimedia has a great significant on students' learning. The availability and surplus of audio visual and textual content used for teaching and learning can make lessons more attractive and effective. Also, the self-production of content that ICT offer can assist teachers to come up with an effective teaching. The use of multimedia could affect teaching and learning positively when properly designed compared to traditional way of instruction in terms of students' performance (Akkoyunlu \& Yilmaz, 2005). Multimedia packages are very useful resources for teaching and Learning in schools. The multimedia packages include: encyclopedia on CD-ROM, drill and practice programmes, educational games, simulations, recreational games, tutorials, educational software such as Microsoft Power point for making lesson presentation using digital projector (Bharatka, 2006). The conventional way of teaching and learning is the chalk-and-talk method and the media used is the printed books. This directional model can be seen in figure 1. The model in figure 1 is the popular technique which has been used for decades as an educational strategy in our institutions of learning. In this model the teacher delivers the concept and the students listen to their teacher teaching the concept. Thus, in this learning mode the students have little or no part in the process of learning while the teacher is chief in command (Orlich, Harder, Callahan \& Gibson, 1998).

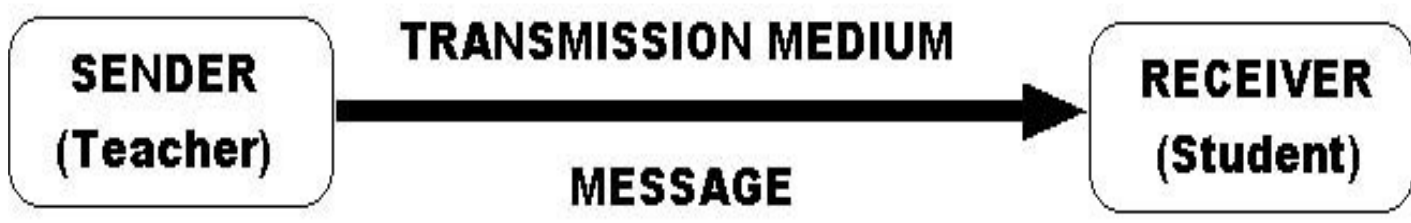

\section{Message: educational content \\ Transmission medium: "chalk-and-talk", Overhead Projector (OHP), Lecture}

Figure 1

The traditional instructional model

Source: Neo \& Neo, (2004)

However, there is going to be an immediate change of great impact on the conventional system of education if multimedia instructional strategy is incorporated into the system of teaching and learning. The instructional materials can be delivered in a multi-sensory environment using the multimedia elements such as video and sound, animation, graphics and text. New paradigm in educational technology is being generated by the use of digital multimedia technologies and strategy (Neo \& Neo, 
2000). Neo and Neo (2000) further stated that multimedia have given a new development mode of teaching and allowed innovative and new methods to deliver instructional aids to students. The terminal effective content when content material is fused of content with multimedia can be expressed in several dimension and made available for the different teaching and learning modes such as the mixed mode, student-centre and teacher-centre (Neo \& Neo, 2000). This is evidence in figure 2.

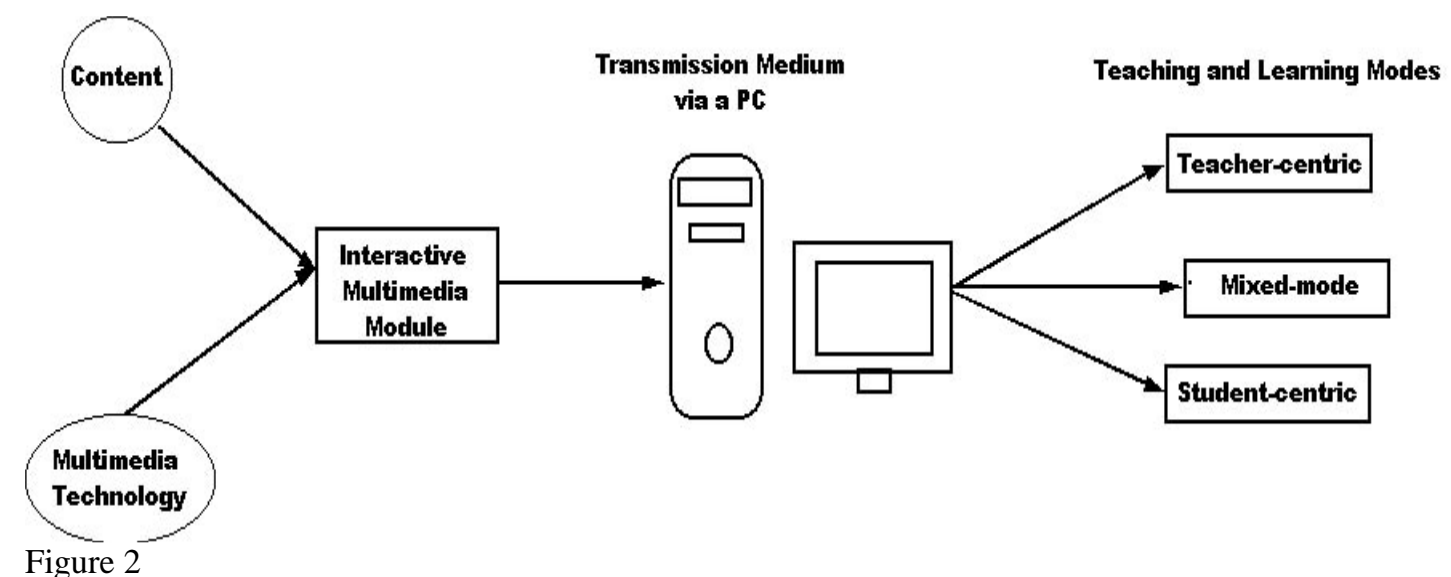

The technology-enhanced instructional communication process

Source: Neo \& Neo, (2004)

Several researchers have investigated issues on learners' academic performance/achievement. Ibrahim (2012), Gambari, Yaki and Olowe (2013) and Dubey (2012) examine the effects of multimedia teaching approach on students' academic performance on chemistry and biology and in Nigeria. The result revealed that academic achievement of pupils exposed to multimedia instructional method and the academic achievement of those exposed to conventional method was significantly difference and the difference was in favour of the experimental group. Arici and Yekta (2005) in their study on the effects of multimedia on students' academic achievement, found no difference between control and experimental group. Şahin (2000) conducted a study on impact of animated-media instructional strategy on student's performance, interest and retention. Findings from this study indicated that the difference in academic performance of students taught using animated-media instructional strategy and those taught using conventional method was significant. The findings further revealed that the difference in the performance of female and male students taught using animated-media strategy was not significant. This findings contradicted the report of Hsu, Liao and Chen (2001) and Dubey (2012) and therefore justify the need for the study of gender in the study.

Meaningful learning is the utmost target of education strives. Retention and comprehension are outcome of an effective and meaningful teaching and learning (Bichi, 2005). Retention is the ability to re3member things learned by an individual at a particular time. Several factors have been identified to influence retention. Bichi (2015) posited that learning should enhance retention while things that lead to interference among learned materials decrease the speed and efficiency of learning. Studies on instructional strategy and retention have allured the attention of many researchers in dated years. For instance, Guwam and Gwandum (2017) examined the how effective is elaboration strategy on students' performance and retention in mathematics. The findings showed that elaboration strategy enable students to have better comprehension of concepts taught and retain more knowledge of mathematics concepts. Ado and Akinbobola (2009) find out the difference in the effectiveness of constructivist teaching method and the traditional method, making reference to students' achievement, retention and attitude. These researchers found that students exposed to constructivist teaching method 
have higher cognitive achievement, more positive attitudes and higher retention level more compared to students taught using the traditional teaching method.

In a social context, gender is an attribute which shows the difference between male and female. Several research have guided to different directions of views on the influence of gender on students' performance in mathematics. Gender difference has been a reality in education particularly subSaharan Africa (Schaumburg, 2001). Schaumburg (2001) stated among the children who are out of school, females are more, and they are bereave of any opportunity to acquire Information Communication and Technology related skills and knowledge in school. Different studies had found out that female students are not much interested in computer compared to male students (Schaumburg, 2001). Likewise, any occupation related to computer and ICT such as computer scientist, system analyst and computer engineering are the dominant career choices for males (Derbyshire, 2008). Anyamene, Nwokolo, Anyachebelu and Anemelu (2012) examined the effect of Computer Assisted Instruction (CAI) packages on senior school students' performance in mathematics. The study that there is no significant difference in the post test score of female and male students when taught using this CAI package. Idris (2007) have revealed in his study that various packages/straregies and techniques of teaching mathematical concepts have improve students' learning and their performance. Inspite this, the result from public examination bodies on students' performance are not encouraging. Thus, there is need to explore multimedia package/strategy that may enhance students' performance in mathematics, hence, this study examines if teaching mathematics using multimedia instructional strategy on senior school students' will improve their performance.

\section{Statement of the Problem}

The federal government of Nigeria is with a strong belief that for the best contribution to be made by higher institutions to National development, ICT must be a necessary need. Etuk, Maria, and Asukwo (2013) is of the opinion that the basics of educational system relys on a crux of dedicated, properly trained, competent and knowledgeable teachers. It was further asserted that students way of think could assisst the teacher to ponder upon and modify teaching and learning strategies to improve the performance and understanding of the students. So, to enhance students' understanding and performance, the need to use a better instructional strategy that would positively influence students' performanmce should be given adequate attention.

The quality and effective of mathematics teaching and learning has been a major challenges and concerns of researchers. This is evidence in students' performance in mathematics (Chief Examiner Report, 2010-2016). The great of eduction stakeholders should be the way of ways of improving teaching and learning of mathematics due to its advantages to individual and to the society as a whole. The use of multimedia could play an important role in this area. So, to enhance the performance of student in solving mathematical problems, this study examined the effects of multimedia instrcutional strategy on senior school students performance and retention in mathematics in Ilorin, Kwara state, Nigeria.

\section{Purpose of the study}

The study was carried out to determine the effects of multimedia on senior school students' performance in mathematics. Specicically, this study;

i. investigated the difference between the performance of students taught mathematics using multimedia instructional strategy and those taught using the conventional classroom method;

ii. ascertained the difference between the performance of male and female students taught mathematics using multimedia instructional strategy;

iii. investigated the interaction effect of treatment on the basis of gender and group of students' performance in mathematics; and 
iv. find out multimedia instructional strategy on students' retention ability in mathematics.

\section{Research Questions}

The following research questions were raised and answered in this study

i. is there any difference in the performance of students' taught mathematics using multimedia instructional strategy and those taught using the conventional classroom method?

ii. will there be any difference in the mean gain score of male and female students' taught mathematics using multimedia instructional strategy?

iii. is there any interactive effect of treatment on the basis of gender and group of students' performance in mathematics?

iv. Is there any difference in the retention level of students expose to multimedia strategy and those expose to conventional method?

\section{Research Hypotheses}

The following research hypotheses were formulated and tested in this study.

$\mathrm{H} 0_{1}$ : There is no significant difference in the performance of students' taught mathematics using multimedia instructional strategy and those taught using the conventional classroom method.

$\mathrm{HO}_{2}$ : There is no significant difference in the mean gain score of male and female studnets' taught mathematics using multimedia instrcutional strategy.

$\mathrm{H}_{3}$ : There is no significant interaction effect of treatment on gender and group of students' performance in mathematics.

$\mathrm{HO}_{4}$ : There is no significant difference in the mean retention score of students exposed to multimedia instructional strategy and those expose to conventional method.

\section{METHOD}

The research type employed in the study was a quasi-experimental type of pre-test, post-test, nonrandomized, control group design. $2 \times 2 \times 1$ factorial design was employed. The first 2 stand for the two groups, which are control and experimental, the second 2 stand for gender (male and female) and 1 stand for retention level.

Pre-test and Post-tests were administered to the two groups (control and experimental) before and after the treatment as shown in table 1 . The groups were pre-tested before the treatment to establish equivalence in ability of the group. Post post-test was administered a week after the post-test to test for the students' retention ability.

Table1

Research design layout

\begin{tabular}{lcccc}
\hline Group & Pre-test & Treatment & Post-test & Post post-test \\
\hline Experimental & $\mathrm{O}_{1}$ & $\mathrm{X}_{1}$ & $\mathrm{O}_{2}$ & $\mathrm{O}_{3}$ \\
\hline Control & $\mathrm{O}_{1}$ & - & $\mathrm{O}_{2}$ & $\mathrm{O}_{3}$ \\
\hline
\end{tabular}

Where: $\mathrm{O}_{1}=$ Pre-test using MPT, $\mathrm{O}_{2}=$ Post-test using MPT, $\mathrm{O}_{3}=$ Post post-test, $\mathrm{X}_{1}=$ Treatment for Experimental group

The target population of this research was senior secondary school II in Ilorin South Local government, Kwara state, Nigeria. Senior school students constitute the population because they wouldn't be preparing for West African Examination Council at the time of this research. Two intact classes of SS II students from co-educational schools were engaged in the study in order to observe the effect of gender on students' performance. One intact class formed the experimental group exposed to the treatment while another intact class without exposing to treatment formed the control group. 
Eighty-one (81) students were sampled: twenty-two (23) male and eighteen (18) female for the experimental group and twenty-one (21) male and Nineteen (19) female for the control group.

The instruments used for the study were: "Multimedia Instructional Package (MIP)" and "Mathematics Performance Test (MPT)". Four mathematics questions were selected for the MPT questions, which are: logarithm, probability, proportion and circle theorems. "Multimedia Instructional Package (MIP)" was developed using the five stages of ADDIE model which are analysis, design, development, implementation and evaluation. The instrument was developed by the researcher, with the help of a professional computer programme and evaluated by computer analyst. The test instrument, "Mathematics Performance Test (MPT)" was made up of 25 items multiple-choice objective test with four options each, selected from validated West African Senior Secondary School Examination. The Mathematics Performance Test was used to measure the performances of students in the experimental and control groups for both the pre-test and post-test. The experimental group was exposed to the treatment using multimedia instructional package. The second group was taught in a conventional teaching method.

The "Multimedia Instructional Package (MIP)" was validated by experts in the department of educational technology, University of Ilorin, Ilorin, Nigeria. The researcher ensured the face and contents validation of "Mathematics Performance Test (MPT)" by given them to experience mathematics teachers and experts in the department of science (mathematics) education, university of Ilorin, Ilorin, Nigeria. The experts assisted the researcher to check the contents whether it measures what it supposes to measure and check if MIP and MPT are of standard. The reliability of the instruments was done using test retest method of three weeks interval on 30 students of nonparticipating schools. The data collected were analysed using Pearson Product Moment Correlation Coefficient. The value of 0.87 was obtained.

Research question one, two, three and four were answered using mean and standard deviation, hypotheses one, two and three were tested using ANCOVA statistic while hypothesis four was tested using t-Test. The students in the experimental group were taught mathematics using "multimedia instructional package" which had been installed to their school computers while the students in the control groups were exposed to the conventional teaching method on the same contents. After the treatment, the items of the instrument were re-shuffled and administered to both experimental and control group as post- test.

\section{FINDINGS}

This section presents the analysis and results of data collected through the administration of the Multimedia instructional package (MIP) and Mathematics Performance Test (MPT).

Research Question 1: is there any difference in the performance of students' taught mathematics using multimedia instructional strategy and those taught using the conventional classroom method?

Table 2

Estimated mean score analysis of students taught mathematics using multimedia instructional package and those taught without

\begin{tabular}{lcccccc}
\hline Group & $\mathrm{N}$ & $\begin{array}{l}\text { Pre-test mean } \\
\text { score }\end{array}$ & $\begin{array}{l}\text { Post-test mean } \\
\text { score }\end{array}$ & $\begin{array}{l}\text { Mean gain } \\
\text { score }\end{array}$ & $\begin{array}{l}\text { \% mean gain } \\
\text { score }\end{array}$ & SD \\
\hline Experimental & 41 & 30.16 & 37.62 & 7.46 & 24.74 & 7.05 \\
\hline Control & 40 & 29.47 & 30.43 & 0.96 & 3.26 & 5.89 \\
\hline
\end{tabular}

Table 2 answered qestion1. Table 2 indicated that the post-test mean score of students taught mathematics using multimedia package (37.62) was higher than the post-test mean score of students 
taught mathematics using conventional method (30.43). Table 2 also, revealed that the mean gain score of the experimental group is higher $(7.46,24.74 \%)$ than the mean gain score of the control group $(0.96,3.26 \%)$. This shows that the experimental group performed better and gain more than the control group and this could be due the treatment (Multimedia Instructional Package) the experimental group was exposed to which was not given to the control group.

HO1: There is no significant difference in the performance of students taught mathematics using multimedia instructional package and those not taught with multimedia instructional package

Table 3

Summary of ANCOVA of post-test performance scores by treatment

\begin{tabular}{llllll}
\hline \multicolumn{1}{c}{ Source } & \multicolumn{1}{c}{ Sum of square } & df & Mean square & F & Sig. \\
\hline Corrected M. & $12435.65^{\mathrm{a}}$ & 2 & 6216.33 & 71.54 & 0.00 \\
\hline Intercept & 50136.96 & 1 & 50136.96 & 211.19 & 0.00 \\
\hline Pre-test & 389.68 & 1 & 389.68 & 5.54 & 0.01 \\
\hline Method & 236.46 & 1 & 360.36 & 22.03 & 0.00 \\
\hline Error & 6140.06 & 78 & 348.89 & & \\
\hline Total & 436215 & 81 & 77.72 & & \\
\hline Corrected Total & 16722.46 & 80 & & & \\
\hline R. Squared & 0.39 & & & & \\
\hline Adjusted Rsq. & 0.34 & & & & \\
\hline Sig. at $p<0.05$ &
\end{tabular}

The result in table 3 showed that there was a significant difference in the performance of students taught mathematics using multimedia instructional package and those not taught mathematics using multimedia instructional package. This was indicated by the calculated F-values $\mathrm{F}(1,80)=22.03$; $\mathrm{p}<$ 0.05 . since the $\mathrm{p}$-value was less than the level of significance $(0.05)$, hypothesis one was rejected. This means that the performance of students taught mathematics using multimedia instructional strategy was significantly better than the performance of students taught mathematics using conventional method.

Research Question 2: Will there be any difference in the mean gain score of male and female students' taught using multimedia instructional strategy?

Table 4

Analysis of the post-test score of male and female students taught mathematics using multimedia instructional package

\begin{tabular}{lccllll}
\hline Gender & $\mathrm{N}$ & $\begin{array}{l}\text { Pre-test mean } \\
\text { score }\end{array}$ & $\begin{array}{l}\text { Post-test mean } \\
\text { score }\end{array}$ & $\begin{array}{l}\text { Mean } \\
\text { gain score }\end{array}$ & \% Mean gain & SD \\
\hline Male & 23 & 30.59 & 38.26 & 7.67 & 25.07 & 8.55 \\
Female & 18 & 29.46 & 37.83 & 8.37 & 28.41 & 6.79 \\
\hline
\end{tabular}

Table 4 gives solution to research question 2. Table 2 showed that the post-test mean score of female students (37.83) was slightly lower than the post-test mean score of the male (38.26). Table 4 also, revealed that the main gain score of female students $(8.37,28.41 \%)$ is higher than the mean gain score of male students $(7.67,25.07 \%)$. This implies that the female students benefited more from the treatment than the male students.

HO2: There is no significant difference in the performance of male and female students taught mathematics using multimedia instructional package. 
Table 5

Summary of ANCOVA of interactive effect of treatment on gender and group

\begin{tabular}{|c|c|c|c|c|c|}
\hline Source & Sum of square & Df & Mean square & $\mathrm{F}$ & Sig. \\
\hline Corrected M. & $6264.17^{\mathrm{a}}$ & 4 & 1566.04 & 123.56 & 0.00 \\
\hline Intercept & 5845.01 & 1 & 5845.01 & 10.41 & 0.00 \\
\hline Pre-test & 326.26 & 1 & 326.26 & 1.31 & 0.06 \\
\hline Gender & 1.6 & 1 & 1.6 & 0.24 & 0.14 \\
\hline Method & 227.23 & 1 & 227.23 & 23.61 & 0.00 \\
\hline Gender*Group & 5.7 & 1 & 5.7 & 1.86 & 0.00 \\
\hline Error & 8995.64 & 76 & 118.36 & & \\
\hline Total & 141024 & 81 & & & \\
\hline Corrected Total & 17822.36 & 80 & & & \\
\hline $\mathrm{R} 2=.29$ (Adjuste & .21) & & & & \\
\hline
\end{tabular}

Table 5 above showed that there was no significant difference in the performance of male and female student in mathematics when exposed to multimedia instructional strategy. The F-value of 0.24 was obtained which is significant at 0.14 that is greater than 0.05 level of significance. Therefore, the null hypothesis of no significant difference in the performance of male and female students taught mathematics using multimedia instructional strategy was accepted.

Research Question 3: is there any interactive effect of treatment on the basis of gender and group of students?

Table 6

Analysis of interactive effect of treatment on gender and group of students' performances in mathematics

\begin{tabular}{|c|c|c|c|c|c|c|c|}
\hline Group & Gender & $\mathrm{N}$ & $\begin{array}{l}\text { Pre-test mean } \\
\text { score }\end{array}$ & $\begin{array}{l}\text { Post-test mean } \\
\text { score }\end{array}$ & $\begin{array}{l}\text { Mean } \\
\text { gain score }\end{array}$ & $\begin{array}{c}\% \text { Mean } \\
\text { gain }\end{array}$ & SD \\
\hline \multirow[t]{3}{*}{ Experiment } & Male & 23 & 30.59 & 38.26 & 7.67 & 25.07 & 8.55 \\
\hline & Female & 18 & 29.46 & 37.83 & 8.37 & 28.41 & 6.79 \\
\hline & Male & 21 & 28.57 & 31.46 & 2.89 & 6.43 & 4.54 \\
\hline Control & Female & 19 & 29.49 & 30.59 & 1.10 & 5.08 & 4.12 \\
\hline
\end{tabular}

Table 6 above revealed that the post-test mean score of male students in experimental group was 38.26 with a mean gain score of 7.67 while the female students in the same group had a mean score of 37.83 with a mean gain score of 8.37 . Also, in the control group, male students had a post-test mean score of 31.46 with a mean gain score of 2.89 while female students in the same group had a mean score of 30.59 with a mean gain score of 1.10 . The gap between the male and female students in the experimental group is very slim (0.7) compare to the gap between the male and female students in the control group (1.79). This shows that there is an interactive effect of treatment on the basis of gender and group of students' performances in mathematics. Therefore, multimedia instructional strategy can bridge gender gap recorded in mathematics.

HO3: There is no significant interaction effect of treatment on the basis of gender and group of students.

Table 5 above showed that F-value of 1.86 which is significant at 0.00 is lesser than 0.05 level of significance. Therefore, the null hypothesis of no significance interaction effect of treatment on the basis of gender and group of students was rejected. This means that treatment interact according to gender and group to cause differences in performance among the students.

Research Question 4: Is there any difference in the retention level of students expose to multimedia strategy and those expose to conventional method?

Anatolian Journal of Education, October 2021 • Vol.6, No.2 
Table 7

t-Test analysis in the retention level using post-post test score of experimental and control group students

\begin{tabular}{llllllll}
\hline Variable & Group & $\mathrm{N}$ & Mean & SD & Df & t-value & p-value \\
\hline & Experimental & 41 & 37.76 & 5.45 & & & \\
\hline Retention & & & & & 79 & 6.47 & .00 \\
\hline & Control & 40 & 32.63 & 3.44 & & & \\
\hline
\end{tabular}

$\mathrm{P}>0.05$ significant

Table 7 reveals that there was a difference in the mean retention scores of students exposed to multimedia instructional strategy and those exposed to conventional method with experimental group having higher mean (37.76) with the control group had the lower mean (32.63). This shows that multimedia instructional strategy yields permanent and meaningful learning that is readily retained and remembered at will by the learner

H04: There is no significant difference in the mean retention score of students exposed to multimedia instructional strategy and those expose to conventional method.

Table 7 also showed that there was a significant difference in the retention level between the experimental and control group, $\mathrm{t}_{(79)}=6.47, \mathrm{p}=0.00$. Since the $\mathrm{p}$-value was lesser than the level of significance (0.05), hypothesis two which states that there is no significant difference in the retention level of students expose to multimedia strategy and those expose to conventional method students taught mathematics using multimedia instructional package was rejected

\section{Summary of Findings}

From the data analysed and the interpretation of the results, it is evident that the academic performance of students taught mathematics using multimedia instructional package was better than those not taught using the package and gender had no significant influence on students performance when exposed to treatment. The findings also revealed that multimedia package improve students retention level though the performance of the control group was improved during the retention period. This could be due to their familiarity with the questions. There is an interactive effective of multimedia instructional strategy on the basis of gender and group of students' performance in mathematics and the interactive effect was significance.

\section{DISCUSSION}

The discussion of findings was presented here in line with the related literatures;

The results as indicated in table 2 and 3 revealed that multimedia form of instruction has an effect on students' performance in mathematics. The result revealed that students taught mathematics in the experimental group have a better mean score than the student's taught mathematics in the control group. This could be due to the treatment (multimedia instructional strategy) administered to experimental group which is not administered to the control group. The findings showed that there was an effect of multimedia instruction on senior school students' performance in mathematics and the effect was significant. This agrees with the view of Ibrahim (2012), Gambari, Yaki and Olowe (2013) and Dubey (2012) who conducted a study on effect of multimedia on student achievement. The findings revealed that there was a significant difference between the performance of student taught with multimedia and student taught without multimedia. The study was in disagreement with the study of Arici and Yekta (2005) who found no significant difference between the experimental and control group but found multimedia as neutral effective on the academic achievement of students.

The study revealed that there was a difference in the performance of male and female students when taught mathematics using multimedia instructional strategy. The finding revealed that female students 
benefited more than the male students on the multimedia instructional strategy with a better mean gain score. Though the result showed that male students performed better than female students when exposed to multimedia instructional strategy but the difference between the performance of male and female students was not significant. Also, the findings revealed that there is an interactive effect of multimedia instructional strategy on gender and group of students' performances in mathematics and the interactive effect was significant. This is an indication that multimedia instructional strategy minimizes gender differences in academic performance. This is in agreement with the study of Vale (2009) who stated that there is no difference between male and female students when better instructional strategy is being employed in mathematics classroom. The finding is in line with the study of Şahin (2000) and Anyamene, Nwokolo, Anyachebelu and Anemelu (2012) who reported that no significant difference in the achievement of male and female students when exposed to animatedmedia strategy. However, this study contradicted the report of Hsu, Liao and Chen (2001), Dubey (2012) and Idris (2007) who found significant difference between male and female students' performance when taught using multimedia instructional strategy.

The study revealed that there was a difference in the retention level of students exposed to multimedia instructional strategy and those not expose to multimedia instructional strategy. The difference was in favour of students exposed to multimedia instructional strategy. The finding was in agreement with Guwam and Gwandum (2017) and Ado and Akinbobola (2009) who stated that teaching instruction strategy improve and stimulate students' retention level. This showed that multimedia instructional package is very helpful package in teaching and learning mathematics and stimulate students interest and in turn improve their performance in mathematics. Finally, the study showed that students in the control group have a slight improved mean score during their retention period and this could be due to familiarity with the questions because the same Post post-test was readministered to the two groups (experimental and control) after a week of post-test.

\section{CONCLUSION}

Based on the findings from the analyzed data the researcher concludes that;

1. There was an effect of multimedia instruction on senior school students' performance in mathematics and the effect was significant. This means that the use of multimedia is a good instuctional strategy that could improve the performance of students in mathematics;

2. There was a difference in the performance of male and female students when taught mathematics using multimedia instructional strategy with female students having a better mean gain score than male students. This means that no matter the gender, students can equally perform better when exposed to a better instructional strategy;

3. there was significant interactive effect of multimedia instructional strategy and gender on students' performance in mathematics. This means multimedia is able to reduce the gender gap between the female students and male students between the group; and

4. There was a difference in the retention level of students exposed to multimedia instructional strategy and those not expose to multimedia instructional strategy and the difference was in favour of students exposed to multimedia instructional strategy

\section{RECOMMENDATIONS}

- In order to enhance the performance of students in both internal and external examination, mathematics teachers should adopt the design and use of multimedia instructional package in teaching and learning.

- Male and female students should be given equal opportunity to participate in classroom activities through the use of multimedia instructional strategy in teaching and learning mathematics. This reduce the gender gap in mathematics performance. 
- $\quad$ Further study should be carried out to determine the effect of multimedia instructional strategy in teaching and learning of calculus and logic. And also, student ability, school type and school facility should be look into as a variable,

\section{REFERENCES}

Ado, I. B., \& Akinbobola, A. O. (2009). Teaching simple interest using constructivist approach. Journal of Issues on Mathematics, 12(1\&2), 47-52.

Agnes, E., Anthony, N., \& Julie, E. I. (2009). Analysis of students' performance in junior secondary school mathematics examination in Bayelsa state of Nigeria. Stud. Home Communication Science, $3(2), 131-134$.

Akinoso, S. O. (2015). teaching mathematics in a volatile, Uncertain, complex and ambiguous (VUCA) world: The use of concrete-representational -abstract instructional strategy. Journal of the international society for teacher Education, 19, 97-107

Akkoyunlu, B., \& Yilmaz, M. (2005). Türetimci çoklu öğrenme kuramı. Hacettepe Üniversitesi Eğitim Fakültesi Dergisi, 28, 9-18.

Albirini, A. A. (2006). Teachers' attitude towards information communication technology. Journal of computers and education, 47, 373-398.

Anyamene, A., Nwokolo, C., Anyachebelu, F., \& Anemelu, V. C. (2012). Effect of computer-assisted packages on the performance of senior secondary students in mathematics in awka, Anambra State, Nigeria. American International Journal of Contemporary Research 2(7).

Arıcı, N., \& Yekta, M. (2005). Meslekive teknik eğitimde çoklu ortam araçları kullanılmış web tabanlı öğretimin öğrenci başarısına etkisi. Ticaret ve Turizm Eğitim Fakültesi Dergisi 1, 144-153.

Bharatka, P. S. (2006). Multimedia: An effective component in digital leaking environment. Retrieved from http://drtc.isibag.ac.in/handle/849/210.

Bichi, S.S. (2005) Effects of problem-solving strategy and enriched curriculum on students' achievement in evaluation concept among secondary school students. [Unpublished Ph.D Dissertation]. Ahmadu Bello University, Zaria, Nigeria

Chapman, D. L. (2013). Multimedia instructional tools and student learning in computer application courses. [Unpublished doctoral dissertation]. University of southern Mississippi, Hattiesburg, MS, USA.

Chief Examiners' Report. (2010-2016). The West African senior school certificate examinations. Lagos, Nigeria.: Megavons (W.A.) Ltd.

Derbyshire, H. (2008). Gender issues in the use of computers in education in Africa.

Dubey, A. K. (2012). An experimental study of impact of multimedia package on achievement of science $i$ of VII class students [Unpublished PhD thesis]. Sundarlal Sharma Open University, Chhattisgarh, Bilaspur.

Enikanolaye, A. J., Salman, M. F., Akanmu, M. A, \& Salami, O. O. (2018). Trends of performance in Nigerian unified tertiary matriculation examination in mathematics from 2012-2016. ABACUS: The Journal of Mathematical Association of Nigeria.42(2), 161-166.

Etuk, N., Maria, E., \& Asukwo, O. (2013). Students perception of teachers characteristics and their attitude towards mathematics in Ovon educational zone, Nigeria. International Educational Studies, 6 (2), 66-77. 
Gambari, A. I, Yaki, A. A., \& Olowe, T. T. (2013). Understanding the concept of digestive system in biology using computer simulation. Chemistry: Bulgarian Journal of Science Education, 22(5),649660.

Guwam, B., Gwandum, G. S. (2017). Effect of elaboration strategy on students' performance and anxiety in bearings and distances at senior secondary two level in Plateau State. The Journal of Mathematical Association of Nigeria. Abacus, 42(2), 8-15

Hsu, Y., Liao, K., \& Chen, C. (2001). A web-based lesson with situated learning in senior school level. Retrieved from ERIC web portal: www.eric.ed.gov/ERICWebportal/recordDetail?accno=ED466592.

Ibrahim, A. (2012). Effect of science process teaching approach on primary school pupils" achievement in basic science and technology in Katsina State [Unpublished M.Ed. Thesis]. Ahmadu Bello University, Zaria, Nigeria.

Idris. (2007). Effect of Geometers' sketchpad on the performance in geometry of malaysian students' achievement and Van Hiele geometric thinking. Malaysian Journal of Mathematical Science, 1(2), 169-180.

Iji, C. O., Emiakwu, S. O. \& Utubaku, R. U. (2015). Effect of problem-based learning on senior secondary school students' achievement in trigonometry in Northern education zone of Cross River State, Nigeria. Journal of Mathematics, 11(1), 16-25.

Kumar, M. K. (2013). Impact of using multimedia package in teaching science. International Journal of Teacher Educational Research (IJTER), 2(12), 1-4

Kyriakidou, M., Chrisostomou, C., \& Bank, F. (2010). Primary teachers " attitude to the use of ICT: A comparative study between Cyprus and the UK. Paper presented at the European Conference on Educational Research. Lahti, Finland

Lindstrom, R. (1994). the business week guide to multimedia presentations: Create dynamic presentations that inspire. McGraw-Hill, New York.

Mbugua, Z. K. (2012). Factors Contributing to students' poor performance in mathematics at Kenya certificate of secondary education in Kenya: A case of Baringo County. Kenya, 2, 87-91.

Mcintosh, N., Oliveras, E., Sullivan, R., \& Whitson, T. (1996). Impact of Information technology on medical school faculty: Performance impact of information on higher education. Baltimore: JIIPIEGO Cooperations, 26-29.

Merrilyn, G. (2010). Using technology to support effective mathematics teaching and learning: what counts? Research Conference, (pp. 67-69).

Mohamed, A. (2010). Factors that Influence Secondary School Students' Performance in Mathematics in Banadir Region, Somalia.

Neo, M., \& Neo, T. K. (2000). Multimedia learning: Using multimedia as a platform for instruction and learning in higher education. Proceedings of the multimedia University International Symposium on Information and Communication Technologies 2000, PJ Hilton, October 5-6, 2000.

Neo, M., \& Neo, T. K. (2004). Integrating multimedia into the Malaysian classroom: Engaging students in interactive learning. The Turkish Online Journal of Educational Technology - TOJET, 3(4), 31 -37

Orlich, D. C., Harder, R. J., Callahan, R. C., and Gibson, H. W. (1998). Teaching strategies: A guide to better instruction. New York: Houghton Mifflin Co. 
Olive, J., \& Makar, K. (2010). Mathematical knowledge and practices resulting from access to digital technologies. International Conference on Multimodal Interfaces , 131-177.

Osu, S. R., Udosen, I. R., \& Akpan, B. P. (2010). Resources availability and level of preparedness of biology teachers. Journal of Education Research and Policies 5, 22-25.

Sahin, T. Y. (2000). İlkoğretim sosyal bilgiler dersinde çoklu ortamların (multimedya) etkililiği. Eğitim Araştırmaları Dergisi 1, 68-73

Schaumburg, H. (2001). Fostering girls' computer literacy level out the gender difference? Paper presented at the NECC conference, June 25-27, Chicago, IL.

Tinio, V. (2003). ICT in education. Retrieved from http://www.apdip.net/publications/iespprimer/ICTi neducation/pf.

Vale, C. (2009). Trend and factors concerning gender in Australis. Retrieved from http://www.faqs.org/periodical. 